\title{
Studi Komparatif Mengenai Word Of Mouth dan Minat Beli Pada Pusat Oleh-Oleh Pempek Candy dan Pempek Vico Palembang
}

\author{
Fany Oktavia \\ Program Studi Ilmu Komunikasi, London School of Public Relations, Jakarta \\ Email: fanyoktavia97@gmail.com
}

\begin{abstract}
Abstrak. Pertumbuhan industri bisnis khususnya usaha di bidang kuliner sedang mengalami kemajuan yang sangat pesat dari tahun ke tahun. Sehingga hal ini membuat kondisi persaingan bisnis di industri restoran semakin kompetitif, dan mendorong masing-masing restoran untuk terus menciptakan perkembangan secara berkelanjutan. Salah satunya adalah dengan menciptakan suatu komunikasi pemasaran yang efektif dan efisien yaitu dengan menggunakan word of mouth pada restoran pempek Candy dan pempek Vico Palembang. Penelitian ini bertujuan untuk melihat seberapa besar pengaruh word of mouth terhadap minat beli pada restoran pempek Candy dan pempek Vico Palembang, serta dikomparasikan untuk mengetahui restoran mana yang lebih dominan dalam mempengaruhi minat beli. Teori yang digunakan dalam penelitian ini adalah teori tindakan beralasan. Metode yang digunakan dalam penelitian ini adalah kuantitatif, dengan jenis penelitian eksplanatif komparatif, dan data yang didapatkan adalah melalui kuesioner yang disebarkan kepada 135 responden. Hasil penelitian menunjukkan bahwa word of mouth berpengaruh secara simultan terhadap minat beli pengunjung restoran pempek Candy Palembang dan restoran pempek Vico Palembang. Berdasarkan hasil uji regresi secara keseluruhan dapat disimpulkan bahwa pengaruh word of mouth terhadap minat beli lebih dominan pada restoran pempek Candy Palembang yaitu sebesar 44,7\% dibandingkan pada restoran pempek Vico Palembang yaitu hanya memiliki pengaruh sebesar 37,9\%.
\end{abstract}

\section{Kata Kunci: Word of Mouth, Minat Beli, Pempek Candy Palembang, Pempek Vico Palembang}

Abstract. The growth of the business industry in particular in the field of a culinary business is undergoing very rapid progress from year to year. So this makes the conditions of business competition in the restaurant industry increasingly competitive, and encourages each restaurant to continue to create sustainable development. One of them is by creating effective and efficient marketing communications by using word og mouth for Candy restaurant and Vico restaurant Palembang. This research aims to look at how big the influence of word of mouth against purchase intention at Candy 
restaurant and Vico restaurant Palembang, and comparisons to find out which restaurants are more dominant in the affect on purchase intention. The theory used in this research are quantitative, comparative research with the kind of explanative, and the data is obtained through a questionnaire that was distributed to 135 respondents. The results show that word of mouth affects simultaneously against the purchase intention of Candy restaurant Palembang and Vico restaurant Palembang. Based on the results of the regression test, overall it can be concluded that the influence of word of mouth against the purchase intention is more dominant at the Candy restaurant Palembang i.e. $44.7 \%$ compared to Vico restaurant Palembang i.e. which only has the influence of $37.9 \%$.

\section{Keywords: Word of Mouth, Purchase Intention, Candy Restaurant Palembang, Vico Restaurant Palembang}

\section{Pendahuluan}

Indonesia merupakan satu dari banyak negara di dunia yang kaya akan berbagai macam kebudayaan. Keanekaragaman kebudayaan dapat menjadi ciri khas suatu daerah, salah satunya adalah aspek kebudayaan makanan tradisional. Makanan tradisional merupakan makanan pokok yang menjadi makanan sehari-hari, baik yang berupa makanan cemilan, atau sajian makanan khusus yang sudah ada secara turun menurun dari zaman nenek moyang. Oleh karena itu, makanan tradisional merupakan suatu bagian dari unsur budaya yang sangat penting.

Industri makanan memberikan kontribusi besar terhadap pertumbuhan ekonomi di Indonesia. Kementrian Perindustrian terus mendorong pengembangan industri makanan. Pada tahun 2015, pertumbuhan industri makanan mencapai 8,16 persen. Pada tahun 2016 industri makanan dan minuman nasional terus menunjukkan kinerja positif dengan tumbuh mencapai 9,82 persen atau sebesar Rp192,69 triliun pada triwulan III 2016. Sehingga menurut Dirjen Industri Agro Kementrian Perindustrian Panggah Susanto, sektor ini menopang sebagian besar pertumbuhan industri non migas dengan pertumbuhan mencapai 4,71 persen (Kementrian Perindustrian Republik Indonesia, 2016).

Cita rasa kuliner dan makanan khas nusantara yang begitu kaya, memberikan keuntungan yang cukup besar bagi para pelaku bisnis oleh-oleh di berbagai daerah. Terlebih pada beberapa tahun terakhir, tingkat ekonomi masyarakat Indonesia terus mengalami kenaikan, sehingga secara tidak langsung dengan kondisi tersebut tentunya dapat mendorong kemampuan 
masyarakat untuk melakukan perjalanan wisata dan berbelanja oleh-oleh khas nusantara (Bisnis UKM, 2017).

Pariwisata berkembang menjadi industri potensial yang dapat memberikan kontribusi besar terhadap pergerakan ekonomi suatu negara. Latar belakang motivasi wisatawan yang berbeda-beda berdampak pada berkembangnya daya tarik wisata yang menawarkan berbagai atraksi wisata sesuai dengan kebutuhan wisatawan dalam melakukan aktivitas wisata (Nurwitasari, 2015).

Kota menjadi sebuah pusat pemerintahan selain dikarenakan lokasi yang strategis juga karena sejarah yang membangun kota itu sendiri. Kuliner suatu daerah bisa menjadi sebuah ikon kota asal makanan itu sendiri dikarenakan memiliki kekhasan yang tidak dimiliki daerah lain dan tentu saja memiliki sejarah yang unik. Dari seluruh daerah di Indonesia, tentunya ada beberapa kota yang merupakan daerah tujuan wisata domestik seperti misalnya Kota Bandung, Bogor, Yogyakarta, Surabaya, Palembang, dan banyak lainnya. Dari setiap daerah yang ada di Indonesia tentunya memiliki ciri khas masingmasing, terutama pada daerah-daerah yang menjadi tujuan wisata domestik.

Kota Palembang merupakan sebuah Ibu Kota dari Provinsi Sumatera Selatan. Palembang adalah kota terbesar kedua di Sumatera yaitu setelah kota Medan. Kota Palembang sangat terkenal dengan Jembatan Amperanya. Merupakan kota yang kaya akan wisata kulinernya, terutama pempek. Kota Palembang terbagi oleh Sungai Musi menjadi Daerah Ulu dan Ilir. Peran Sungai Musi sangat besar pengaruhnya terhadap kehidupan masyarakat Kota Palembang, mulai dari sebagai sumber air, mata pencaharian, serta sebagai tujuan utama wisata Kota Palembang. Terlepas dari Sungai Musi serta Jembatan Amperanya yang begitu ikonik, Palembang juga memiliki banyak makanan khas yang digemari oleh tiap orang yang mencicipinya.

Menurut data yang bersumber dari Dinas Kebudayaan Pariwisata dan Kebudayaan Provinsi Sumatera Selatan (Southsumatratourism, 2017), pada tahun 2015 kota Palembang mengalami peningkatan yang cukup signifkan dalam jumlah kunjungan wisatawan nuasantara yaitu berjumlah 5.704.959, dan tentunya di tahun 2016 tetap menunjukkan peningkatan jumlah kunjungan wisatawan nusantara yaitu sebesar 14,13 persen dari tahun sebelumnya. Dimana pada tahun 2015 jumlah 5.704 .959 wisatawan nusantara meningkat menjadi 7.118.516 wisatawan nusantara.

Kota Palembang tentunya adalah kota yang terkenal sebagai kota pempek yang berpotensi mengembangkan industri pada makanan tradisional, 
ditambah bahwa makanan rakyat khas daerah ini sangat diminati oleh warga Palembang sendiri maupun para pendatang, tanpa terkecuali dari turis domestik dan dari mancanegara (IDN Times, 2016). Makanan khas Palembang berbahan utama ikan ini memiliki pasar yang cukup menjanjikan seiring dengan berkembangnya belanja online. Dalam beberapa dua tahun terakhir bermunculan bisnis pempek online karena persoalan pengiriman sudah tidak menjadi masalah. Kuliner ini dapat dikemas dengan cara di vakum sehingga dapat awet dan lebih tahan lama selama dalam melakukan proses pengiriman ke luar kota maupun hingga ke luar negeri.

Salah satunya, bisnis pempek online PT Pos Indonesia yang bertumbuh pesat hingga tiga kali lipat sejak mulai diluncurkan pada tahun 2012 yakni awalnya dari 1 hingga 2 ton per bulan, dan sampai pada tahun 2016 dapat mencapai menjadi 7 hingga 8 ton per bulan. Hal ini diperkuat dengan artikel yang berjudul "Pemerintah kota Palembang Dorong Pempek Go International”, (Republika, 2017). Akibat volume pengiriman pempek yang meningkat tajam, PT. Pos menggandeng beberapa perusahaan pempek yang sudah terkenal untuk melakukan pengiriman pempek baik di dalam negeri maupun ke luar negeri, seperti IP pempek, pempek Candy, pempek Pak Raden, pempek Vico, pempek Beringin, dan lain sebagainya.

Tabel 1. Data Top Brand Pempek di Palembang (2017)

\begin{tabular}{ccc}
\hline Merek & Persentase & TOP \\
\hline Pempek Candy & $25.80 \%$ & TOP \\
\hline Pempek Pak Raden & $21.50 \%$ & TOP \\
\hline Pempek Vico & $18.80 \%$ & TOP \\
\hline Pempek Saga & $11.70 \%$ & \\
\hline Pempek Beringin & $8.70 \%$ & \\
\hline
\end{tabular}

Sumber: Data dari website Wisata Palembang

Hingga saat ini pempek Candy dan Pempek Vico Palembang telah berhasil dan sukses menjadi restoran pempek yang dikenal TOP di Palembang, dan tentunya juga telah menjadi pilihan utama, baik bagi masyarakat Palembang sendiri maupun dari kota lain hingga dari negara lain. Dengan melalui citra merek yang baik, diharapkan dapat mempengaruhi minat beli konsumen, karena citra merek yang baik dapat mempengaruhi pangsa pasar. Namun kepada orang-orang yang sama sekali belum pernah mencoba dan 
mengkonsumsi Pempek Candy, dan Pempek Vico, tentu saja belum mengetahui hal spesial apa yang membuat kedua restoran pempek tersebut sebagai icon restoran pempek yang terbaik di Palembang, orang-orang tersebut hanya mendengar pendapat, komentar serta rekomendasi dari orang lain mengenai Pempek Candy, dan Pempek Vico Palembang.

Berdasarkan hasil penelitian yang pernah dilakukan sebelumnya oleh (1) Rahma Nurvidiana, (2) Kadarisman Hidayat, (3) Yusri Abdillah (2015), dinyatakan bahwa word of mouth terjadi ketika konsumen merasa puas atau tidak puas terhadap suatu produk, dan menceritakan hal tersebut kepada orang lain. Word of mouth dapat berpengaruh positif bagi pelaku bisnis ketika word of mouth dapat mempengaruhi individu untuk mengkonsumsi produk yang mereka hasilkan. Di sisi lain word of mouth dapat memberikan dampak yang negatif bagi pelaku bisnis ketika seorang individu tidak mau untuk mengkonsumsi produk yang dihasilkannya yang disebabkan oleh pengalaman buruk yang didapatnya dari penyampai word of mouth tersebut.

Sebelum memutuskan untuk melakukan pembelian suatu produk seringkali seorang konsumen mencari informasi mengenai produk yang akan dibelinya. Pencarian informasi tersebut dilakukan untuk mengetahui kesesuaian kegunaan produk dengan kebutuhan konsumen tersebut. Ketika seorang konsumen merasa kegunaan akan sebuah produk sesuai dengan apa yang dibutuhkannya, akan timbul sebuah rasa ingin memilikinya. Hal ini dapat disebut dengan minat beli, Menurut Kotler dan Keller yang dialih bahasakan oleh Bob Sabran (2009, p. 137) menyatakan bahwa minat beli adalah perilaku konsumen yang muncul sebagai respon terhadap objek yang menunjukkan keinginan seseorang untuk melakukan pembelian.

\section{Kajian Pustaka}

\section{Proses Respons Konsumen AISAS}

Konsep AISAS mencakup lima dimesi, yaitu Attention, Interest, Search, Action dan Share. AISAS adalah model proses respon konsumen yang dikembangkan oleh agen periklanan Dentsu pada tahun 2004. Di dalam AISAS, konsumen mengikuti proses dimana mereka menjadi sadar dan perhatian terhadap produk (Attention), menjadi tertarik (Interest), mencari informasi yang relevan melalui internet (Search), membeli produk (Action), dan mengirimkan ulasan setelah menggunakan produk (Share). Model AISAS merupakan bagian dari perkembangan model AIDMA (Attention, Interest, Desire, Memory, Action) yang diusulkan oleh S. Roland Hall guna untuk 
mempresentasikan proses respon dari konsumen. AIDMA merupakan tindakan yang diambil oleh orang-orang yang menonton iklan TV dari pada perilaku berbelanja di toko-toko (Suryani, 2008, p. 68).

Ketika membutuhkan suatu produk dengan keterlibatan yang tinggi, pelanggan akan melakukan pencarian yang lebih mendalam dibandingkan produk-produk dengan keterlibatan yang rendah. Oleh karena itu, Dentsu (dalam Sugiyama dan Andree, 2011, p. 51) mengemukakan sebuah model komunikasi pemasaran yang didapat dari perkembangan teknologi, yang diberi nama dengan model AISAS (Attention $\rightarrow$ Interest $\rightarrow$ Search $\rightarrow$ Action $\rightarrow$ Share).

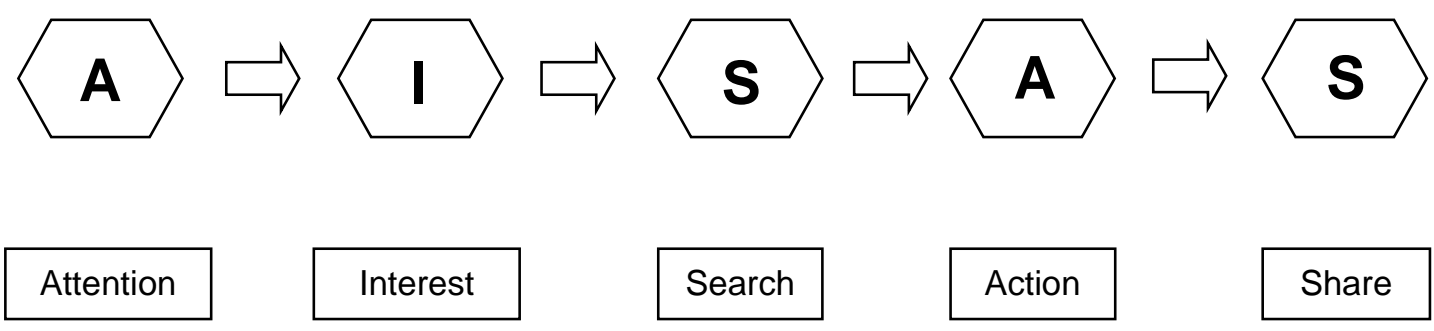

Psychological changes (passive)

Action (active)

Gambar 3. AISAS Model, dari Sugiyama and Lee (2011), Dentsu Way 3rd Edition

Melalui konsep AISAS, perusahaan melihat bahwa consumer sebagai orang yang aktif, yang dapat melakukan pencarian akan informasi dan membagikan informasi yang sudah didapat kepada orang lain. Konsep AISAS adalah sebagai berikut: (Sugiyama dan Andree, 2011).

a. Attention

Pesan atau iklan haruslah menarik perhatian khalayak sasarannya, maka dari itu pesan atau iklan memerlukan bantuan lain seperti ukuran (untuk media cetak atau durasi air time untuk media penyiaran), penggunaan warna, tata letak, jenis huruf yang ditampilkan, serta berbagai suara khusus untuk iklan radio dan televisi. Hal yang pokok dan sangat perlu untuk diperhatikan adalah bahwa perhatian calon konsumen harus didapatkan.

b. Interest

Setelah perhatian akan pesan sudah berhasil dilakukan, persoalan yang dihadapi adalah apakah konsumen memiliki minat dan keingintahuan 
lebih. Untuk itu konsumen harus dirangsang agar mau membaca dan mengikuti pesan-pesan yang disampaikan

c. Search

Search merupakan keuntungan bagi konsumen, karena dengan adanya mesin pencari, sebelum mengambil keputusan, maka konsumen akan berusaha mencari informasi sebanyak-banyaknya melalui search engine. Product review, tulisan di blogs, website-website lain, dan semua informasi akan muncul dengan jelas di mesin pencari, inilah yang membantu konsumen untuk mengambil keputusan.

d. Action

Action adalah tindakan konsumen, pada tahap ini the real experience tercipta. Proses interaksi langsung antara konsumen dengan sales channel, transaksi, delivery, konsumsi, hingga after sales service merupakan satu kesatuan pengalaman yang benar-benar harus dipertahankan dan dijaga agar sesuai bahkan melebihi ekspektasi dari konsumen.

e. Share

Share adalah hasil setelah konsumen merasakan semua pengalaman interaksi mereka dengan produk atau brand, konsumen akan membagi pengalamannya kepada orang lain melalui email, chat, blogs, mailist, online forum, dan lain-lain. Sehingga pengalaman baik ataupun buruk akan mudah tersebar ke banyak orang.

Berikut dapat digambarkan proses respons konsumen yang terjadi secara tidak berurutan.

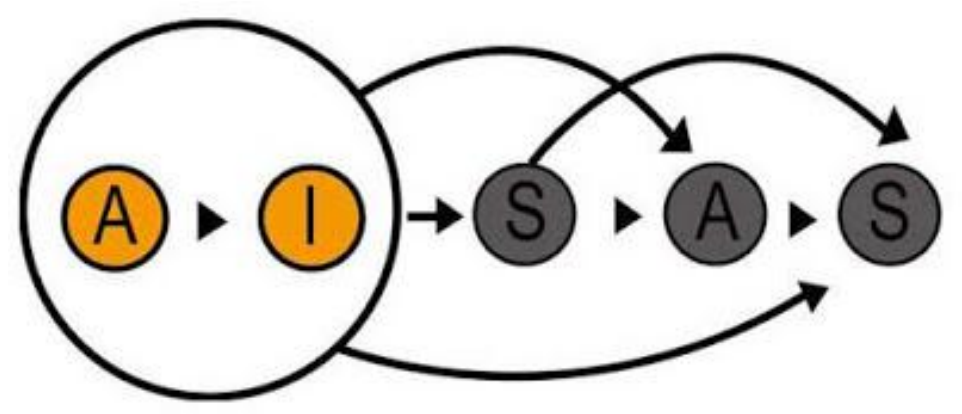

Gambar 4. AISAS as a nonlinear model, dari Sugiyama dan Andree, 2011

\section{Teori Tindakan Beralasan (Theory of Reasoned Action)}

Theory of Reasoned Action pertama kali dicetuskan oleh Ajzen pada tahun 1980. Teori ini disusun menggunakan asumsi dasar bahwa manusia berperilaku 
dengan cara yang sadar, ditentukan oleh keinginan individu tersebut yang ditentukan oleh dua variabel independent termasuk sikap dan norma subyektif, serta mempertimbangkan segala informasi yang tersedia. Diperbaharui dengan teori perilaku direncanakan (theory of planned behavior) oleh Ajzen (1991), telah digunakan selama dua dekade masa lalu untuk meneliti keinginan dan perilaku berbagi.

Teori tindakan beralasan berusaha untuk menetapkan faktor-faktor Sikap (Attitude), Norma Subyektif (Subjective Norm) yang mengacu pada tekanan sosial yang dirasakan untuk melakukan atau tidak melakukan perilaku (Ajzen, 1991)., Niat Perilaku (Behavioral Intention), serta Perilaku (Behavioral) yang menentukan konsistensi sikap dan perilaku. Teori ini berasumsi bahwa orang akan berperilaku secara cukup rasional.

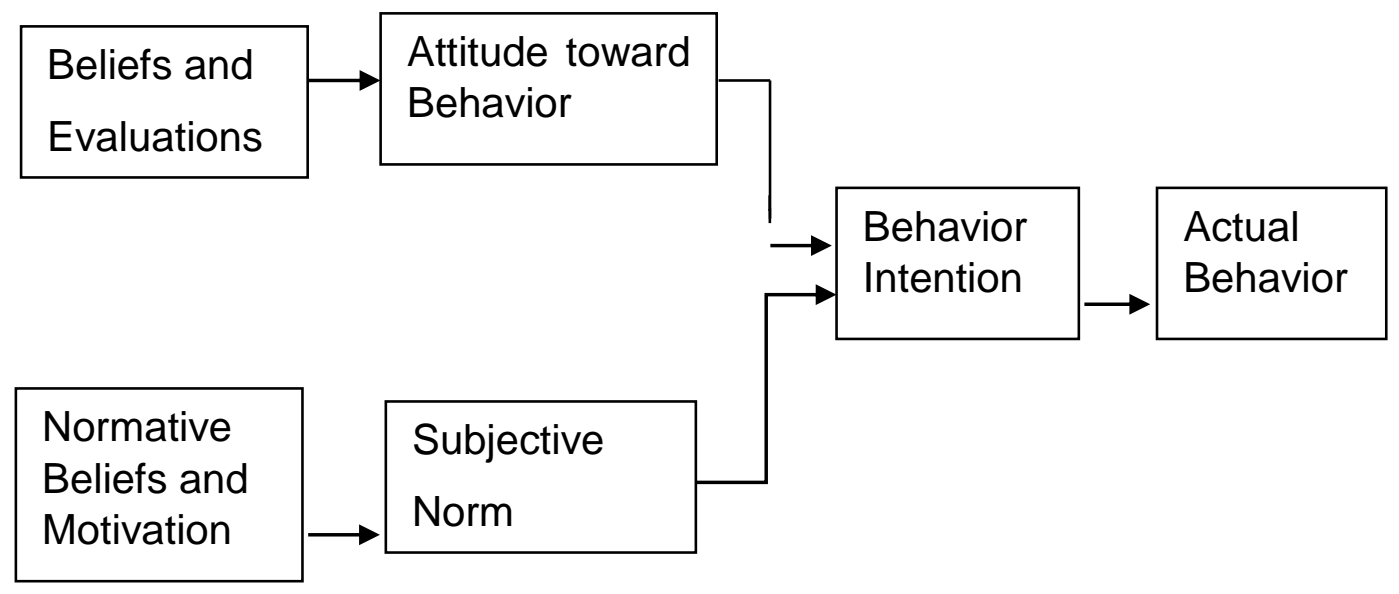

Gambar 5. Teori tindakan beralasan (Theory of Reasoned Action), dari Fishbein dan Ajzen 1975, dalam Jogiyanto (2007, p. 26).

Pada tahun 1969, Wicker memimpin survei dan review literature secara luas terhadap hubungan sikap dan perilaku. Fishbein dan Ajzen ikut dalam survei dan review tersebut. Mereka ingin mengeksplorasi cara untuk memprediksi perilaku dan hasil (outcome). Mereka berasumsi bahwa individu biasanya cukup rasional dan menggunakan informasi yang tersedia secara sistematis dan Individu akan mempertimbangkan akibat dari tindakannya sebelum Ia memutuskan menampilkan atau tidak suatu perilaku. Setelah mereview semua penelitian yang pernah dilakukan oleh para ahli sebelumnya, mereka mengembangkan teori yang dapat memprediksi dan memahami perilaku dan sikap. Teori ini yang disebut teori tindakan beralasan (Theory of Reasoned Action) (Jogiyanto, 2007). 
Teori tindakan beralasan mengemukakan bahwa sebab terdekat (proximal cause) timbulnya perilaku bukan sikap, melainkan niat (intention) untuk melaksanakan perilaku itu. Niat merupakan pengambilan keputusan seseorang untuk melaksanakan suatu perilaku. Pengambilan keputusan oleh seseorang untuk melaksanakan suatu perilaku merupakan suatu hasil dari proses berpikir yang bersifat rasional. Proses berpikir yang bersifat rasional berarti bahwa dalam setiap perilaku yang bersifat sukarela maka akan terjadi proses perencanaan pengambilan keputusan yang secara kongkret diwujudkan dalam niat untuk melaksanakan suatu perilaku.

Teori tindakan beralasan (Theory of Reasoned Action) mempunyai tiga langkah, yaitu:

a. Memprediksi perilaku seseorang dari niatnya.

b. Maksud perilaku dapat diprediksi dari dua variabel utama, yaitu sikap seseorang terhadap perilaku dan persepsinya tentang apa yang seharusnya orang lain lakukan.

c. Sikap terhadap perilaku diprediksi dengan menggunakan kerangka nilai harapan yang telah diperkenalkan.

\section{Marketing Komunikasi}

Marketing Komunikasi tentunya memiliki fungsi dan peran tersendiri. Marketing terdiri dari strategi bauran pemasaran (marketing mix) dimana organisasi atau perusahaan mengembangkan untuk mentransfer nilai melalui pertukaran untuk pelanggannya. Kotler dan Armstrong (2008, p. 62) berpendapat bahwa, "bauran pemasaran (marketing mix) adalah kumpulan alat marketing taktis terkendali yang dipadukan perusahaan untuk menghasilkan respons yang diinginkannya di pasar sasaran."

Marketing mix terdiri dari empat komponen biasanya disebut "empat $\mathrm{P}$ $\left(4 \mathrm{P}^{\prime} \mathrm{s}\right), "$ yaitu :

1. Product (Produk), yang artinya kombinasi barang dan jasa yang ditawarkan perusahaan kepada pasar sasaran

2. Price (Harga), yang artinya jumlah uang yang harus dibayarkan pelanggan untuk memperoleh produk

3. Place (Tempat), yang di dalamnya meliputi kegiatan perusahaan yang membuat produk tersedia bagi pelanggan sasaran.

4. Promotion (Promosi), artinya aktivitas yang menyampaikan manfaat produk dan membujuk pelanggan membelinya. 


\section{Consumer Behavior}

Perilaku konsumen (consumer behavior) adalah kegiatan-kegiatan individu yang secara langsung terlibat dalam mendapatkan dan mempergunakan barang-barang dan jasa-jasa tersebut didalamnya proses pengambilan keputusan pada persiapan dan penentuan kegiatan-kegiatan tersebut (Dharmmesta dan Handoko, 2008, p. 10).

Para pemasar berkewajiban untuk memahami konsumen, mengetahui apa yang dibutuhkannya, apa seleranya, dan bagaimana ia mengambil keputusan, sehingga pemasar dapat memproduksi barang dan jasa yang sesuai dengan kebutuhan konsumen. Pemahaman yang mendalam mengenai konsumen akan memungkinkan pemasar dapat memengaruhi keputusan konsumen, sehingga konsumen mau membeli apa yang ditawarkan oleh pemasar. Persaingan yang ketat antar merek menjadikan konsumen memiliki posisi yang semakin kuat dalam posisi tawar menawar (Setiadi, 2008).

Sedangkan dalam pengertian umum perilaku adalah segala perbuatan atau tindakan yang dilakukan oleh makhluk hidup, pengertian perilaku dapat dibatasi sebagai keadaan jiwa untuk berpendapat, berfikir, bersikap, dan lain sebagainya yang merupakan refleksi dari berbagai macam aspek, baik fisik maupun non fisik. Perilaku juga diartikan sebagai suatu reaksi psikis seseorang terhadap lingkungannya, reaksi yang dimaksud digolongkan menjadi dua, yakni:

1. Bentuk pasif (tanpa dengan tindakan nyata atau konkret)

2. Dalam bentuk aktif (dengan tindakan konkret)

Perilaku konsumen pada hakikatnya untuk memahami "why do consumers do what they do". Dari beberapa definisi yang telah disebutkan diatas dapat di simpulkan bahwa perilaku konsumen adalah semua kegiatan, tindakan serta proses psikologis yang mendorong tindakan tersebut pada saat sebelum membeli, ketika membeli, menggunakan, menghabiskan, produk dan jasa setelah melakukan hal-hal di atas atau kegiatan mengevaluasi.

\section{Word of Mouth (WOM)}

Menurut Esti Susanti, (2009, p. 1) word of mouth yaitu menyampaikan atau menceritakan apa yang dialami dan bagaimana produk yang telah dibelinya kepada pihak lain.

Terdapat dua sumber utama yang menghasilkan word of mouth diantaranya yaitu Reference Group dan Opinion Leader. Bentuk-bentuk grup yang paling penting antara lain keluarga, teman dekat serta, rekan kerja. Menurut 
Shimp (2012, p. 286) opinion leader adalah seseorang yang sering mempengaruhi sikap-sikap atau perilaku yang visibel dan individu lainnya.

Shimp juga berpendapat bahwa seorang pemimpin opini juga mempunyai fungsi penting yaitu: mereka memberi informasi kepada orang lain tentang produk-produk baru, mereka memberikan saran serta mengurangi persepsi resiko yang diterima oleh pengikutnya dalam pembelian produk baru, dan mereka menawarkan umpan balik positif untuk mendukung atau memperjelas keputusan yang telah diambil oleh pengikut.

Mahendrayasa et al (2014) menyatakan bahwa word of mouth terbentuk dalam suatu grup karena pada kenyataanya konsumen lebih percaya orang lain dari pada iklan yang diluncurkan oleh perusahaan.

Ada dua jenis model word of mouth yaitu Organic Word of Mouth dan Amplified Word of Mouth (dalam Womma, 2007, p. 1-6). Organic word of mouth adalah word of mouth yang terjadi secara alami, orang yang merasa puas pada sebuah produk akan membagi antusiasme mereka. Schiffman dan Kanuk (2008, p. 28) mengemukakan bahwa komunikasi tidak hanya menghubungkan konsumen dengan produsen tetapi juga menghubungkan konsumen dengan lingkungan sosialnya, yaitu komunikasi pemasaran yang berasal dari perusahaan dan berasal dari konsumen.

Aktivitas yang dapat meningkatkan organic word of mouth meliputi: (a) fokus pada pelanggan; (b) meningkatkan kualitas produk dan kegunaan; (c) menanggapi keprihatinan dan kritik; (d) membuka dialog dan mendengarkan orang; dan (e) produktif loyalitas pelanggan.

Amplified word of mouth adalah word of mouth yang terjadi karena di atur dan di tetapkan oleh perusahaan. Amplified word of mouth dilakukan ketika perusahaan melakukan kampanye yang dirancang untuk mendorong atau mempercepat penyampaian word of mouth kepada konsumen. Kondisi dimana perusahaan berusaha menginformasikan produknya kepada masyarakat sehingga masyarakat ke depannya dapat mengenal dan membeli produk perusahaan tersebut.

Aktivitasnya meliputi: (a) menciptakan komunitas; (b) mengembangkan alat-alat yang memungkinkan orang untuk berbagi pendapat mereka; (c) pemberi saran dan penyebar informasi untuk secara aktif mempromosikan produk, (d) memberikan pendapat informasi yang mereka dapat berbagi; (e) menggunakan publisitas yang dirancang untuk menciptakan buzz atau memulai percakapan; (f) mengidentifikasi dan menjangkau orang-orang berpengaruh dan masyarakat; dan (g) meneliti percakapan online. 
Menurut Sernovitz (2012, p. 19-23), menyebutkan bahwa ada lima elemen-elemen (Five T's) yang dibutuhkan untuk word of mouth agar dapat menyebar yaitu:

\section{Talkers}

Dalam elemen ini adalah kita harus tahu siapa pembicara dalam hal ini pembicara adalah konsumen kita yang telah mengkonsumsi produk atau jasa yang telah kita berikan, terkadang orang lain cenderung dalam memilih atau memutuskan suatu produk tergantung kepada konsumen yang telah berpengalaman menggunakan produk atau jasa tersebut atau biasa disebut dengan referral pihak yang merekomendasikan suatu produk atau jasa.

\section{Topics}

Adanya suatu word of mouth karena tercipta suatu pesan atau perihal yang membuat mereka berbicara mengenai produk atau jasa, seperti halnya pelayanan yang diberikan, karena produk kita mempunyai keunggulan tersendiri, tentang perusahaan kita, lokasi yang strategis.

\section{Tools}

Setelah kita mengetahui pesan atau perihal yang membuat mereka berbicara mengenai produk atau jasa tersebut dibutuhkan suatu alat untuk membantu agar pesan tersebut dapat berjalan, seperti website game yang diciptakan untuk orang-orang bermain, contoh produk gratis, postcards, brosur, spanduk, melalui iklan di radio apa saja alat yang bisa membuat orang mudah membicarakan atau menularkan produk anda kepada temannya.

\section{Taking Part (partisipasi perusahaan)}

Suatu partisipasi perusahaan seperti halnya dalam menanggapi respon pertanyaan-pertanyaan mengenai produk atau jasa tersebut dari para calon konsumen dengan menjelaskan secara lebih jelas dan terperinci mengenai produk atau jasa tersebut, melakukan follow up ke calon konsumen sehingga mereka melakukan suatu proses pengambilan keputusan.

\section{Tracking (pengawasan)}

Hasil word of mouth marketing perusahaan setelah suatu alat tersebut berguna dalam proses word of mouth dan perusahaan pun cepat tanggap dalam merespon calon konsumen, perlu pula pengawasan akan word of 
mouth yang telah ada tersebut yaitu dengan melihat hasil seperti dalam kotak saran sehingga terdapat informasi banyaknya word of mouth positif atau word of mouth negatif dari para konsumen.

Menurut Babin, Barry (2005, p. 133-139), dalam word of mouth communication terdapat beberapa hal yang digunakan untuk mengukur apakah word of mouth communication tersebut berhasil atau tidak, yaitu:

1. Membicarakan

Kondisi di mana kemauan seseorang untuk membicarakan hal-hal positif tentang kualitas produk kepada orang lain. Konsumen berharap mendapatkan kepuasan yang maksimal dan memiliki bahan yang menarik untuk dibicarakan dengan orang lain.

2. Mempromosikan

Seseorang mungkin menceritakan produk yang pernah di konsumsinya tanpa sadar ia mempromosikan produk kepada orang lain (teman atau keluarganya).

3. Merekomendasikan

Konsumen menginginkan produk yang dapat memuaskan dan memiliki keunggulan dibandingkan dengan produk yang lain, sehingga dapat di rekomendasikan kepada orang lain.

4. Mendorong

Dorongan terhadap teman atau relasi untuk melakukan transaksi atas produk dan jasa. Kondisi dimana konsumen menginginkan timbal balik yang menarik pada saat mempengaruhi orang lain untuk memakai produk atau jasa yang telah diberitahukan tersebut.

5. Menjual

Menjual tidak berarti harus mengubah konsumen menjadi salesman, tetapi kondisi dimana konsumen berhasil mengubah (transform) konsumen lain yang tidak percaya, memiliki persepsi negatif dan tidak mau mencoba merek kita menjadi percaya, persepsi positif dan akhirnya mencoba.

\section{Minat Beli}

EXPOSE - Jurnal Ilmu Komunikasi, Vol. 2. No. 1, Mei 2019 - 61 
Minat beli konsumen merupakan keinginan seorang konsumen terhadap pemenuhan kebutuhan dan keinginan yang tersembunyi dalam benak konumen. Minat beli konsumen selalu terselubung dalam setiap diri individu yang mana tidak seorang pun bisa tahu apa yang diinginkan dan diharapkan oleh konsumen (Malik et al., 2013).

Asseal (2012, p. 53) mendefiniskan minat beli konsumen timbul dan terbentuk setelah konsumen melakukan evaluasi terlebih dahulu terhadap suatu merek dan akan melakukan pembelian terhadap merek yang dapat memberikan tingkat paling tinggi dari kepuasan yang diharapkan. Minat beli merupakan kecenderungan konsumen untuk membeli suatu merek atau mengambil tindakan yang berhubungan dengan pembelian yang diukur dengan tingkat kemungkinan konsumen melakukan pembelian.

\section{Hubungan Word Of Mouth (WOM) dengan Minat Beli}

Word Of mouth merupakan salah satu faktor yang mempengaruhi keputusan pembelian melalui minat beli, dengan adanya word of mouth maka sebuah perusahaan akan mendapat keuntungan tanpa harus mengeluarkan biaya. Karena dengan menyebarnya berita baik tentang sebuah produk tersebut maka pembelian akan semakin meningkat sehingga profit perusahaan juga meningkat.

Banyaknya literature-literature yang menyatakan bahwa word of mouth merupakan salah satu kekuatan di dalam pasar. Kekuatan word of mouth terletak pada kemampuannya dalam merekomendasikan (referral). Word of mouth adalah sebuah hasil dari suatu program pemasaran yang dikelola dengan sangat baik serta dapat pula meningkatkan strategi dalam komunikasi pemasaran (Fadillah, 2015).

Dalam penelitian ini dimana menggunakan variabel word of mouth dan minat beli, maka dimensi-nya pun sampai pada tahap share yaitu kondisi dimana muncul minat untuk membicarakan produk tersebut kepada orang lain. Pada penelitian ini menggunakan model komunikasi AISAS (Attention, Interest, Search, Action, Share) sebagai acuan dalam pembuatan operasionalisasi variabel.

\section{Hipotesis}

Penelitian yang menggunakan hipotesis adalah penelitian yang menggunakan pendekatan kuantitatif. Hipotesis juga dapat dinyatakan sebagai jawaban teoritis terhadap rumusan masalah penelitian, belum sebagai jawaban yang empirik. 
Hipotesis dalam penelitian ini adalah sebagai berikut:

Ho: Tidak ada pengaruh antara Word of Mouth terhadap minat beli pada pempek Candy dan pempek Vico.

Ha : Ada pengaruh Word of Mouth terhadap minat beli pada pempek Candy dan pempek Vico.

\section{Metode Penelitian}

Penelitian ini menggunakan metodologi kuantitatif, karena peneliti berusaha menemukan kebenaran yang berlaku umum untuk topik yang diteliti dan menguji teori serta hipotesis. Penelitian ini menggunakan pendekatan paradigma klasik, yang merupakan sebuah paradigma untuk menempatkan ilmu-ilmu sosial seperti halnya ilmu-ilmu alam fisika. Menempatkan ilmu sosial sebagai metode yang terorganisir untuk mengkombinasikan antara deductive logic dengan pengamatan empiris, serta bertujuan untuk menemukan hubungan sebab akibat yang dapat digunakan untuk memprediksi pola-pola umum dari gejala sosial tertentu (Pasaribu, Mahadian dan Sugandi, 2016). Berdasarkan tingkat eksplanasi, jenis penelitian yang digunakan adalah eksplanatif komparatif. Studi perbandingan atau studi komparatif umum dipergunakan untuk menyusun penelitian ilmiah dengan generalisasi penelitian yang lintas batas dan tidak cenderung pada etnik budaya sosial suatu masyarakat tertentu.

Metode yang digunakan dalam penelitian ini adalah survei, guna untuk mengumpulkan informasi mengenai variabel dan responden yang dianggap sebagai sekelompok populasi (obyek) dengan menggunakan kuesioner.

Populasi dalam penelitian ini, adalah tidak diketahui, tetapi ditujukan kepada orang-orang yang mengetahui dan pernah mengunjungi restoran Pempek Candy dan Pempek Vico Palembang. Sampel yang akan digunakan dalam penelitian adalah responden dengan umur minimal 17 tahun, dan orangorang yang mengetahui dan pernah mengunjungi restoran Pempek Candy dan Pempek Vico Palembang.

Teknik sampling yang digunakan peneliti untuk menentukan sampel adalah non probability sampling. Non probability sampling menurut Sugiyono (2010, p. 218) adalah teknik pengambilan sampel yang tidak memberi peluang atau kesempatan sama bagi setiap unsur atau anggota populasi untuk dipilih menjadi sampel. Metode sampel pada penelitian ini adalah purposive sampling sebagai teknik pengambilan sampel, yaitu metode penetapan responden untuk dijadikan sampel berdasarkan atas kriteria (Siregar, 2013, p. 33). Kriteria 
responden yang dimaksud dalam penelitian ini adalah orang-orang yang mengetahui dan pernah mengunjungi restoran Pempek Candy dan Pempek Vico Palembang.

Apabila populasi tidak diketahui, menurut Hair dkk (2010) merekomendasikan jumlah sampel minimal adalah 5 kali dari jumlah item pertanyaan dalam kuesioner.

Indikator dalam penelitian ini terdiri dari 1 variabel bebas dan 1 variabel terikat. Total pertanyaan dalam penelitian ini adalah 19 pertanyaan, sehingga minimal ukuran sampel penelitian ini adalah $19 \times 5=95$. Jadi jumlah sampel yang diambil dalam penelitian ini adalah 95 responden. Namun, untuk mengurangi kesalahan, besarnya sampel yang ditetapkan adalah 135 orang. Seluruh indikator dalam penelitian ini menggunakan skala likert. Menurut (Siregar, 2013, p. 25) skala likert adalah skala yang dapat digunakan untuk mengukur sikap, pendapat, dan persepsi seseorang mengenai suatu objek atau suatu fenomena tertentu.

Tabel 5. Operasionalisasi Variabel $X$

\begin{tabular}{|c|c|c|c|}
\hline Variabel X & Dimensi & Indikator & Skala \\
\hline \multirow[t]{4}{*}{ Word of mouth } & Talkers & $\begin{array}{l}\text { a. Talker mempunyai } \\
\text { informasi yang kuat } \\
\text { b. Talker memiliki } \\
\text { tingkat pengetahuan } \\
\text { yang luas }\end{array}$ & Likert \\
\hline & Topics & $\begin{array}{l}\text { a. Topic mengenai } \\
\text { informasi produk } \\
\text { b. Topic mengenai } \\
\text { kepuasan terhadap } \\
\text { produk }\end{array}$ & Likert \\
\hline & Tools & $\begin{array}{l}\text { a. Pesan tersampaikan } \\
\text { dengan tepat } \\
\text { b. Pesan tersampaikan } \\
\text { dengan jelas }\end{array}$ & Likert \\
\hline & Taking part & $\begin{array}{l}\text { a. Mengajak konsumen } \\
\text { untuk menggunakan }\end{array}$ & Likert \\
\hline
\end{tabular}




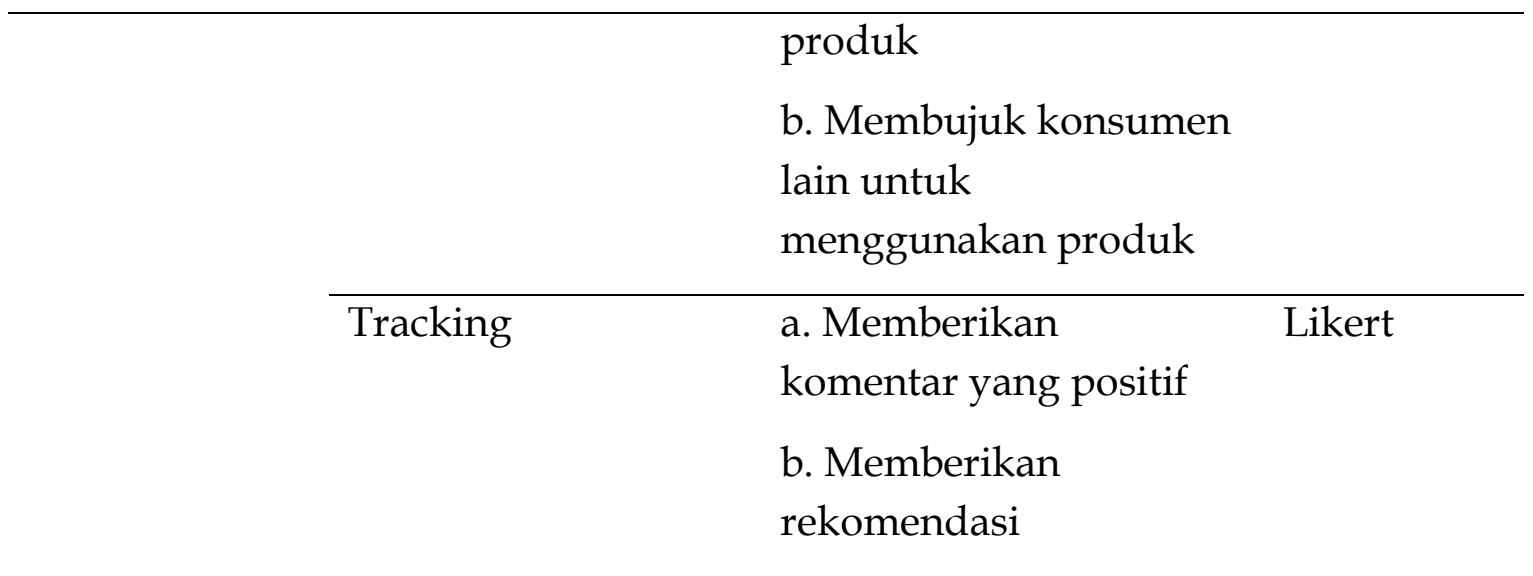

Sumber: Sernovitz (2012, p. 19-23)

Tabel 6. Operasionalisasi Variabel Y

\begin{tabular}{llll}
\hline Variabel Y & \multicolumn{1}{c}{ Dimensi } & \multicolumn{1}{c}{ Indikator } & Skala \\
\hline Minat Beli & Pencarian informasi & a. Mendapatkan & Likert \\
& lanjut & informasi secara lebih & \\
& & \\
& & b. Melakukan \\
kunjungan ke outlet & \\
& & \\
& & \\
& Kerdekat & \\
& memauan untuk & a. Informasi produk & Likert \\
& Keinginan untuk & a. Mencoba produk yang & Likert \\
& mencoba produk & akan dibeli & \\
& & b. Kemudahan navigasi & \\
\hline
\end{tabular}

Sumber : Yoestini dan Eva (2007, p. 270)

\section{Hasil dan Pembahasan}

\section{Uji Validitas Variabel Word of Mouth (X)}

Antara butir item pertanyaan pada kuesioner variabel word of mouth $(X)$ dengan skor total menunjukkan seluruh nilai $r$ hitung lebih besar daripada nilai $\mathrm{r}$ tabel yaitu 0,361. Sehingga hal ini menujukkan bahwa seluruh butir pertanyaan di variabel $X$ adalah valid.

Uji Validitas Variabel Minat Beli (Y) 
Antara butir item pertanyaan pada kuesioner variabel minat beli (Y) dengan skor total menunjukkan seluruh nilai $r$ hitung lebih besar daripada nilai $r$ tabel yaitu 0,361. Sehingga hal ini menujukkan bahwa seluruh butir pertanyaan di variabel $Y$ adalah valid.

\section{Hasil Uji Reliabilitas Variabel Word Of Mouth (X)}

\begin{tabular}{cr}
\hline \multicolumn{2}{c}{ Reliability Statistics } \\
\hline $\begin{array}{c}\text { Cronbach's } \\
\text { Alpha }\end{array}$ & $\begin{array}{c}\text { N of } \\
\text { Items }\end{array}$ \\
\hline .957 & 26
\end{tabular}

Sumber : Data Olahan Peneliti, 2018

Hasil Uji Reliabilitas Variabel Minat Beli (Y)

Reliability Statistics

\begin{tabular}{r|r}
\hline $\begin{array}{c}\text { Cronbach's } \\
\text { Alpha }\end{array}$ & \multicolumn{1}{c}{$\begin{array}{c}\mathrm{N} \text { of } \\
\text { Items }\end{array}$} \\
\hline .942 & 12
\end{tabular}

Sumber : Data Olahan Peneliti, 2018

Analisis Korelasi dan Regresi

Tabel 24. Model Summary Restoran Pempek Candy Palembang

\begin{tabular}{lrrrr}
\hline \multicolumn{5}{c}{ Model Summary } \\
\hline Mode & & \multicolumn{4}{c}{$\begin{array}{c}\text { Adjusted R } \\
\text { Square }\end{array}$} & $\begin{array}{l}\text { Std. Error of } \\
\text { the Estimate }\end{array}$ \\
\hline 1 & R & R Square & Squar \\
\hline a. Predictors: (Constant), XCandy & & \\
\hline
\end{tabular}

Sumber : Data Olahan Peneliti, 2018

Tabel 25. Model Summary Restoran Pempek Vico Palembang

\begin{tabular}{lrrrr}
\hline \multicolumn{5}{c}{ Model Summary } \\
\hline Mode & & & Adjusted R & Std. Error of \\
1 & R & R Square & Square & \begin{tabular}{l} 
the Estimate \\
\hline 1
\end{tabular} \\
\hline
\end{tabular}


a. Predictors: (Constant), XVico

Sumber : Data Olahan Peneliti, 2018

ANOVA Restoran Pempek Candy Palembang

\begin{tabular}{|c|c|c|c|c|c|c|}
\hline \multicolumn{7}{|c|}{ ANOVA $^{a}$} \\
\hline \multicolumn{2}{|c|}{ Model } & $\begin{array}{l}\text { Sum of } \\
\text { Squares }\end{array}$ & $\mathrm{df}$ & $\begin{array}{l}\text { Mean } \\
\text { Square }\end{array}$ & F & Sig. \\
\hline \multirow[t]{3}{*}{1} & Regression & 1736.303 & 1 & 1736.303 & 107.672 & $.000^{\mathrm{b}}$ \\
\hline & Residual & 2144.734 & 133 & 16.126 & & \\
\hline & Total & 3881.037 & 134 & & & \\
\hline a. $\mathrm{De}$ & dent Varia & YCandy & & & & \\
\hline
\end{tabular}

Sumber : Data Olahan Peneliti, 2018

Tabel 27. ANOVA Restoran Pempek Vico Palembang

\begin{tabular}{|c|c|c|c|c|c|c|}
\hline \multicolumn{7}{|c|}{ ANOVAa $^{a}$} \\
\hline \multirow{2}{*}{\multicolumn{2}{|c|}{ Model }} & Sum of & & Mean & & \\
\hline & & Squares & $\mathrm{df}$ & Square & $\mathrm{F}$ & Sig. \\
\hline \multirow[t]{3}{*}{1} & Regression & 1167.161 & 1 & 1167.161 & 81.205 & $.000^{\mathrm{b}}$ \\
\hline & Residual & 1911.610 & 133 & 14.373 & & \\
\hline & Total & 3078.770 & 134 & & & \\
\hline a. Dep & sendent Varia & le: YVico & & & & \\
\hline
\end{tabular}

Sumber : Data Olahan Peneliti, 2018

Koefisien Restoran Pempek Candy Palembang

\section{Coefficients $^{\mathrm{a}}$}




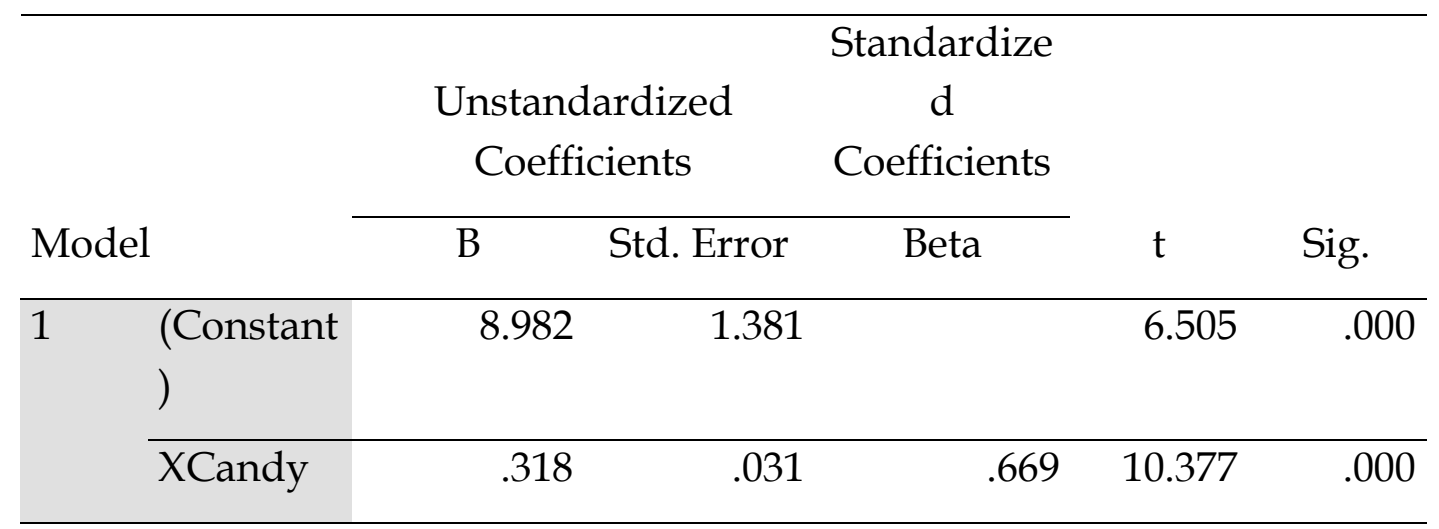

a. Dependent Variable: YCandy

Sumber : Data Olahan Peneliti, 2018

Koefisien Restoran Pempek Vico Palembang

\section{Coefficients $^{\mathrm{a}}$}

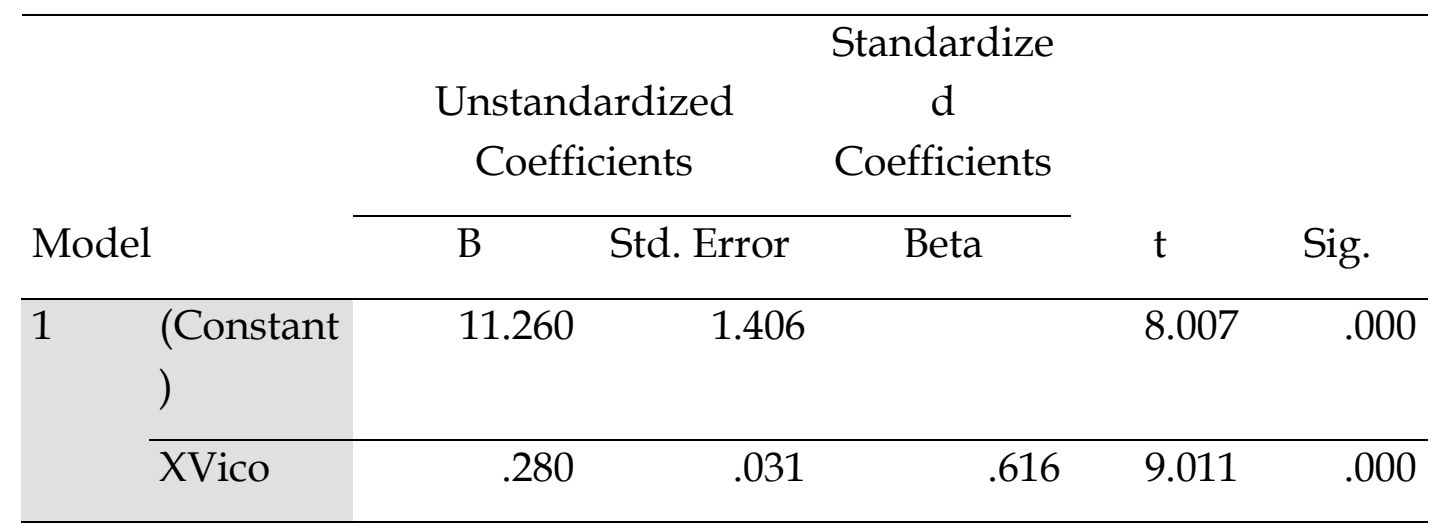

a. Dependent Variable: YVico

Sumber : Data Olahan Peneliti, 2018

\section{Pembahasan}

Terdapat pengaruh yang signifikan dan positif antara word of mouth terhadap minat beli pengunjung restoran pempek Candy Palembang dan pengunjung restoran pempek Vico Palembang. Apabila dikomparasikan mendapatkan hasil bahwa pengaruh variabel $X$ (word of mouth) terhadap variabel Y (minat beli) lebih besar dan lebih dominan pada restoran pempek Candy Palembang yaitu sebesar 0,318 dibandingkan pada restoran pempek Vico Palembang yaitu sebesar 0,280.

Hasil penelitian menyatakan bahwa word of mouth berpengaruh positif dan signifikan terhadap minat beli. Hasil tersebut mendukung teori tindakan beralasan yang menyatakan bahwa norma subyektif merupakan salah satu faktor dasar seseorang dalam menentukan sebuah niat. Hasil penelitian 
menyatakan bahwa word of mouth berpengaruh positif dan signifikan lebih besar terhadap minat beli pada restoran pempek Candy Palembang dibandingkan pada restoran pempek Vico Palembang, sehingga hal ini mengindikasikan bahwa restoran pempek Candy Palembang lebih memiliki kualitas positif di benak pengunjung sehingga pengunjung terdorong untuk membicarakan restoran pempek Candy Palembang atau melakukan word of mouth terhadap orang lain, dibandingkan dengan restoran pempek Vico Palembang yang memiliki pengaruh lebih kecil.

\section{Kesimpulan dan Saran}

\section{Kesimpulan}

Berdasarkan hasil penelitian yang telah dilakukan, maka kesimpulan yang didapatkan adalah sebagai berikut:

1. Berdasarkan hasil penelitian, arah pengaruh positif dan signifikan secara simultan dari word of mouth terhadap minat beli pengunjung restoran pempek Candy Palembang, dan pengunjung restoran pempek Vico Palembang. Setelah dikomparasikan, menghasilkan bahwa pengaruh yang lebih besar atau lebih dominan terdapat pada restoran pempek Candy Palembang dibandingkan pada restoran pempek Vico Palembang. Sehingga hal tersebut mengindikasikan bahwa pengunjung restoran pempek Candy Palembang lebih merasa puas dan merekomendasikan restoran kepada orang lain sehingga menyebabkan komunikasi pemasaran secara word of mouth dibandingkan pada restoran pempek Vico Palembang. Semakin baik dan semakin positif word of mouth yang terjadi pada restoran menyebabkan peningkatan pada minat beli pengunjung.

2. Pada restoran pempek Candy Palembang besarnya pengaruh variabel $X$ (word of mouth) terhadap variabel Y (minat beli) sebesar 0,318. Pada restoran pempek Vico Palembang besarnya pengaruh variabel $X$ (word of mouth) terhadap variabel Y (minat beli) sebesar 0,280.

\section{Saran}

Setelah melakukan penelitian ini, maka terdapat beberapa saran akademis yang dapat diberikan, yaitu :

1. Dari hasil penelitian, diharapkan agar hasil dari penelitian ini dapat menjadi bahan kajian untuk pengembangan studi ilmu komunikasi 
pemasaran, khususnya untuk penelitian mengenai word of mouth terhadap minat beli pada perusahaan produk atau jasa.

2. Hasil penelitian menyatakan bahwa pada restoran pempek Candy Palembang, variasi variabel $\mathrm{Y}$ (minat beli) dapat dijelaskan dengan variabel X (word of mouth) sebesar 44,7\%, sedangkan sisanya sebesar $55,3 \%$ dijelaskan oleh variasi dari faktor-faktor lain. Artinya terdapat faktor lain yang cukup dominan dalam mempengaruhi variabel Y (minat beli), oleh karena itu bagi mahasiswa lain yang ingin melakukan penelitian mendalam dengan topic yang sama, maka dapat mencoba dengan meneliti lebih dalam mengenai dimensi mana yang lebih dominan yang terdapat pada word of mouth (talkers, topic, tools, taking part, tracking). Guna melengkapi penelitian yang sudah dibuat sebelumnya.

3. Hasil penelitian menyatakan bahwa pada restoran pempek Vico Palembang, variasi variabel $\mathrm{Y}$ (minat beli) dapat dijelaskan dengan variabel X (word of mouth) sebesar 37,9\%, sedangkan sisanya sebesar $62,1 \%$ dijelaskan oleh variasi dari faktor-faktor lain. Artinya terdapat faktor lain yang cukup dominan dalam mempengaruhi variabel Y (minat beli), oleh karena itu bagi mahasiswa lain yang ingin melakukan penelitian mendalam dengan topic yang sama, maka dapat mencoba dengan meneliti lebih dalam mengenai dimensi mana yang lebih dominan yang terdapat pada word of mouth (talkers, topic, tools, taking part, tracking). Guna melengkapi penelitian yang sudah dibuat sebelumnya.

\section{Daftar Pustaka}

Asseal, H. (2012). Consumer Behaviour and Marketing Action. (4 $4^{\text {th }}$ ed.). New York: Kent Publishing.

Babin., Barry, J., Yong, L. K., Kim, E. J., \& Griffin, M. (2005). Modeling Consumer Satisfication And Word Of Mouth: Restaurant Petronage Korea. Journal of Service Marketing, 19(3), 133-139. Diperoleh dari : http://journals.sagepub.com/doi/abs/10.1177/109467059800100102

Dharmmesta, B. S. dan Handoko, T. H. (2008). Manajemen Pemasaran: Analisa Perilaku Konsumen. Yogyakarta: Liberty.

Fadillah, D. (2015). Model Komunikasi “WOM" Sebagai Strategi Pemasaran Efektif. Jurnal Humanika, 15(1), 66-74. Diperoleh dari : https:/ / media.neliti.com/media/publications/18142-ID-modelkomunikasi-wom-sebagai-strategi-pemasaran-efektif.pdf 
Gambaran data top brand pempek di Palembang. Diperoleh dari http:/ / wisatapalembang.com/

Gambaran jumlah wisatawan di kota Palembang. (2017). Diperoleh dari : https:// southsumatratourism.com/

Gambaran kota Palembang. (2017). Diperoleh dari :

https://travel.idntimes.com/destination/erny/11-kekayaanpalembang-yang-jadi-kebanggaan-masyarakatnya/full

Gambaran tentang peningkatan bisnis oleh-oleh. (2017). Diperoleh dari:

https:/ / bisnisukm.com/ prospek-cerah-bisnis-oleh-oleh-di-berbagaidaerah.html

Gambaran tentang pertumbuhan industri makanan. (2016). Diperoleh dari : www.kemenperin.go.id/artikel/16650/Industri-Makanan-danMinuman-Tumbuh-9,8-Persen-Triwulan-III-2016

Hair et al. (2010). Multivariate Data Analysis. (7th ed.). Pearson Prentice Hall. Harnojoyo. (2017, September 09). Pemkot Palembang Dorong Pempek GoInternational. Leisure Republika. Diperoleh dari: http:/ / www.republika.co.id

Jogiyanto, H, M. (2007). Sistem Informasi Keperilakuan. Yogyakarta: CV Andi Offset.

Kotler, P., dan Armstrong, G. (2008). Prinsip-prinsip Pemasaran. Jakarta: Erlangga.

Kotler, P., dan Keller, K. L. (2009). Manajemen Pemasaran Jilid 2. (13 ${ }^{\text {th }}$ ed.). Terjemahan Bob Sabran, MM. Jakarta: Erlangga.

Mahendrayasa, A. C., Kumadji, S., \& Abdillah, Y. (2014). Pengaruh Word Of Mouth Terhadap Minat Beli Serta Dampaknya Pada Keputusan Pembelian. Jurnal Administrasi Bisnis (JAB), 12(1), 1-7. Diperoleh dari: https://media.neliti.com/media/publications/82799-ID-pengaruhword-of-mouth-terhadap-minat-be.pdf

Malik, M. E., Ghafoor, M. M., Iqbal, H. K., Ali, Q., Hunbal, H., Noman, M., \& Ahmad, B. (2013). Impact of Brand Image and Advertisement on Consumer Buying Behavior. World Applied Sciences Journal, 23(1), 117122.

Diperoleh dari

https://pdfs.semanticscholar.org/e45a/180119f4437153ac9251526c0a2f5 7695d48.pdf 
Nurvidiana, R., Hidayat, K., \& Abdillah, Y. (2015). Pengaruh Word of Mouth Terhadap Minat Beli Serta Dampaknya Pada Keputusan Pembelian. Jurnal Administrasi Bisnis, 22(2), 1-8. Diperoleh dari : http://administrasibisnis.studentjournal.ub.ac.id/index.php/jab/article /view/891

Nurwitasari, A. (2015). Pengaruh Wisata Gastronomi Makanan Tradisional Sunda Terhadap Keputusan Wisatawan Berkunjung ke Kota Bandung Sekolah Tinggi Pariwisata Bandung. Jurnal Barista, 2(1), 92-102.

Diperoleh dari: http://stpbandung.ac.id/ejournal/index.php/v01/article/viewFile/34/30

Pasaribu, D. H., Mahadian, A. B., \& Sugandi, M. S. (2016). Pengaruh Penggunaan Media Televisi dan Internet Terhadap Kepuasan yang Diperoleh Setelah Menggunakan Media (Studi Pada Masyarakat Kampung Cyber RT 36 RW 09 Taman Kelurahan Patehan, Kecamatan Kraton, Yogyakarta). E-Proceeding of Management, 3(3) 3699-3706. Diperoleh dari:

file:///C:/Users/user/Downloads/16.04.2215_jurnal_eproc.pdf

Sernovitz, A. (2012). Word of Mouth Marketing: How Smart Companies Get People Talking (3rd ed.). Diperoleh dari:

http://www.wordofmouthbook.com/download/first-chapter.pdf

Setiadi, N. (2008). Perilaku Konsumen. Jakarta: Kencana.

Shimp. (2012). Advertising Promotion and Other Aspects of Integrated Marketing Communications. USA. South Western Educational Publishing.

Siregar, S. (2013), Metode Penelitian Kuantitatif: Dilengkapi dengan Perbandingan Perhitungan Manual dan SPSS. Jakarta: Kencana Prenada Media Group.

Sugiyama, K., dan Andree, T. (2011). The Dentsu Way: Secrets of Cross Switch Marketing Form World Most Innovative Advertising Agency. New York: Mc Graw Hill.

Sugiyono. (2010). Statistika untuk Penelitian. Bandung: Alfabeta.

Suryani, T. (2008). Perilaku konsumen. Yogyakarta: Graha Ilmu.

Susanti, E. (2009). Word of Mouth Communication. Bandung: Alfabeta.

WOMMA. (2007). An introduction to WOM Marketing. Jurnal WOM, 101(1), $1-6$. 
Yoestini., \& Rahma, E. S. (2007). Analisis pengaruh Kualitas Pelayanan dan Citra Merek trhadap Minat Beli dan Dampaknya Pada Keputusan Pembelian (Studi pada Pengguna Telepon Seluler Merek Sony Ericson Di Kota Semarang). Jurnal Sains Pemasaran Indonesia, 6(3), 270. Diperoleh dari : https://ejournal.undip.ac.id/index.php/jspi/article/view/14156 